Nat. Hazards Earth Syst. Sci., 19, 2715-2725, 2019

https://doi.org/10.5194/nhess-19-2715-2019

(C) Author(s) 2019. This work is distributed under

the Creative Commons Attribution 4.0 License.

\title{
First reported case of thunderstorm asthma in Israel
}

\author{
Yoav Yair ${ }^{1}$, Yifat Yair ${ }^{2}$, Baruch Rubin ${ }^{2}$, Ronit Confino-Cohen ${ }^{3}$, Yosef Rosman ${ }^{3}$, Eduardo Shachar ${ }^{4}$, and \\ Menachem Rottem ${ }^{5}$ \\ ${ }^{1}$ Interdisciplinary Center (IDC) Herzliya, School of Sustainability, Herzliya, Israel \\ ${ }^{2}$ Hebrew University of Jerusalem, Faculty of Agriculture, Food and Environment, Rehovot, Israel \\ ${ }^{3}$ Meir Medical Center, Kfar Saba, Israel \\ ${ }^{4}$ Rambam Medical Center, Haifa, Israel \\ ${ }^{5} \mathrm{Ha}$ 'Emek Medical Center, Afula, Israel
}

Correspondence: Yoav Yair (yoav.yair@idc.ac.il)

Received: 20 April 2019 - Discussion started: 30 April 2019

Revised: 2 October 2019 - Accepted: 25 October 2019 - Published: 3 December 2019

\begin{abstract}
We report on the first recorded case of thunderstorm asthma in Israel, which occurred during an exceptionally strong eastern Mediterranean multicell thunderstorm on 25 October 2015. The storms were accompanied by intensive lightning activity, severe hail, downbursts and strong winds followed by intense rain. It was the strongest lightningproducing storm ever recorded by the Israeli Lightning Detection Network (ILDN) since it began operations in 1997. After the passage of the gust front and the ensuing increase in particle concentrations, documented by air-quality sensors, the hospital emergency room (ER) presentation records from three hospitals - two in the direct route of the storm (Meir Medical Center in Kfar Saba and Ha'Emek in Afula) and the other just west of its ground track (Rambam Medical Center in Haifa) - showed that the amount of presentation of patients with respiratory problems in the hours immediately following the storm increased compared with the average numbers in the days before. This pattern is in line with that reported by Thien et al. (2018) for the massive thunderstorm asthma epidemic in Melbourne, Australia. The increase in patient presentations to the emergency rooms persisted for an additional $48-72 \mathrm{~h}$ before going back to normal values, indicating that it was likely related to the multi-cell outflow. We discuss how the likelihood of incidence of such public health events associated with thunderstorms will be affected by global trends in lightning occurrence.
\end{abstract}

\section{Introduction}

Thunderstorms and lightning are natural hazards, lethal and destructive with important implications for human societies. They are often accompanied by severe weather, hail and flash floods that entail significant economic and human losses (Yair, 2018; Petrucci et al., 2019; Cooper and Holle, 2019). Public health effects of thunderstorms that are not related to direct lightning strikes of people may be the result of flooding, fallen trees, objects hurled by strong winds, impact of heavy hail, smoke from ignited forest fires and the consequences of disruptions to daily routines such as industrial accidents, loss of electricity, car accidents and limitation of air travel (Krausmann et al., 2011; Yair et al., 2019).

Research had shown that during the development stage of thunderstorms, updrafts carry surface aerosols and pollen particles into the cloud, where the high humidity and contact with liquid water causes pollen to rupture (Knox, 1993; Taylor et al., 2004; Miguel et al., 2006; Vaidayanathan et al., 2006). At the mature stage of thunderstorm development, characterized by intense electrical activity and precipitation (typically lasting tens of minutes), downdrafts carry such pollen fragments to the ground. When the downdrafts impinge on the surface they diverge and the outflow enhances the concentrations of airborne particles by causing uplift of additional concentration of pollen and dust particles into the air (Fig. 1). When such outflows occur in dry desert areas, it often leads to the formation of the dust-wall known as "haboob", which makes the gust front clearly visible and can be seen many YouTube videos (Williams et al., 2007). The 


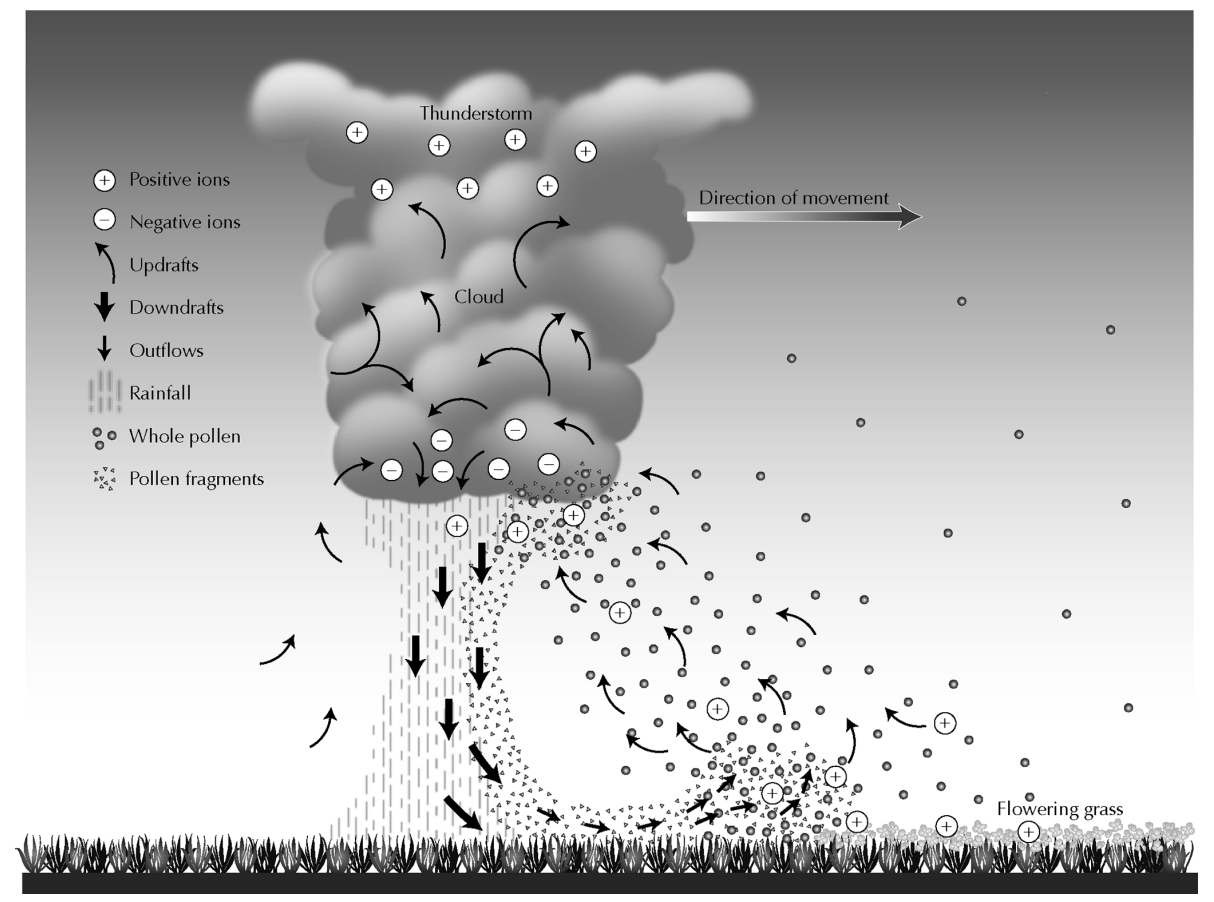

Figure 1. A schematic description of the mechanism that enhances the concentrations of airborne aerosols (either pollution particles or pollen) ahead of a mature thunderstorm (Taylor and Jonsson, 2004).

gust front - the storm-scale boundary caused by the outflow from the thunderstorm - quickly spreads and diverges from beneath it and propagates along the storm track (Marks et al., 2001). The airborne pollen fragments and particles often release allergens in the size range $<2.5 \mu \mathrm{m}$ that can be inhaled into the respiratory system and cause an acute allergic response. If occurring during the flowering season of specific plants, it may result in "thunderstorm asthma" epidemics (Bellomo et al., 1992; Packe and Ayers, 1985; Venables et al., 1997; Wardman et al., 2002; Dales et al., 2003; D'Amato et al., 2016, 2017), which are expressed as severe respiratory problems, especially in sensitive populations (infants, the elderly and people with prior allergic susceptibility). A thorough review of the present theories of thunderstorm asthma mechanisms is presented by Harun et al. (2019) and some unique cases are described below.

Grass pollen is a well-known cause of hay fever and allergic asthma, and has been implicated as the cause of two cases of thunderstorm asthma epidemics, in Melbourne (1987/1989) and in London (1994). Knox (1993) discussed the fact that grass pollen is too large to penetrate into the lower airways and trigger an allergic response and suggested that the osmotic shock caused by rainwater led to the rupture of grass pollen particles and the release of the major allergen Lol p 5.

Nasser and Pulimood (2009) reviewed the role of fungal spores such as Alternaria in outbreaks of thunderstorm asthma and showed that the sudden increase in spore con- centrations in the air following large-scale thunderstorm cold flows affects atopic, sensitive people, and may lead to an asthmatic response. There are numerous reports from many countries about cases of thunderstorm asthma (Dabrera et al., 2012; Andrew et al., 2017; Beggs, 2017). For example, the Wagga Wagga epidemic in Australia on 30 October 1997 led to 215 emergency room (ER) visits by asthmatic subjects with 41 hospitalizations, a fact that created an unusual burden on the health services there (Girgis et al., 2000). The most extreme case on record occurred in Melbourne, Australia, in November 2016 (Thien et al., 2018), when a thunderstorm asthma epidemic following a gust front induced by a multicell thunderstorm system resulted in more than 3000 presentations to ERs in hospitals for allergy and respiratory problems, with 10 fatalities (and Table 1 in Harun et al., 2019). The allergic response of the population followed (or was prompted by) a chain reaction commencing with the dynamics of the cold outflow from the thunderstorm. D'Amato et al. (2015) characterized the main aspects of thunderstormassociated asthma epidemics (based on their Table 2) as follows: (a) the epidemics are limited to seasons when there are high concentrations of airborne allergenic and/or fungal spores; (b) there is a close temporal association between the start of the thunderstorm and the onset of the epidemics; (c) there are not high levels of pollution-related gases and particles during the thunderstorm asthma outbreak; (d) people who stay indoors with their windows closed are not affected; and (e) there is a major risk for subjects who are 
not optimally treated for asthma, and subjects with polleninduced allergic rhinitis and without a prior history of asthma are also at risk

While this definition of thunderstorm asthma focuses on the allergic responses to airborne pollen or fungal spores, some reports consider other environmental factors such as humidity, temperature and pressure changes (Rossi et al., 1993). A chemical effect of lightning activity that may also play a role in thunderstorm asthma epidemics is the production of significant amounts of $\mathrm{NO}$ and $\mathrm{O}_{3}$ near the surface. Ozone by itself is a potent oxidizer and is known to provoke a severe respiratory response when inhaled (Molfino et al., 1991; Gleason et al., 2014). Indeed, Campbell-Hewson et al. (1994) considered several types of pollen and fungal spores, but also ozone concentrations and lightning, in the context of a thunderstorm asthma epidemic in Cambridge and Peterborough in southern England in June 1994. They reported an increase by a factor $\sim 2$ of ozone concentration ( $45 \mathrm{ppb}$ compared with daily average of $28.7 \mathrm{ppb}$ ) and high pollen counts before the rain and concluded that the causes of the epidemic were likely multifactorial. It should be pointed out that although there were 37 lightning strikes in that region, the authors did not attribute the rise in ozone concentrations to lightning but rather to local pollution. This aspect of lightning activity was not considered in the present study.

A thorough review published by the World Allergy Organization (D'Amato et al., 2015) surveyed the expected changes in the occurrence of thunderstorm asthma and concluded that people with hypersensitivity to pollen allergy should be advised to stay indoors when there are clear indications that thunderstorm activity is expected. Such early warning capabilities for lightning are becoming operational in some countries. For example, the Lightning Potential Index (LPI) is used in the Weather and Forecasting Research (WRF) model (Lynn and Yair, 2010; Lynn et al., 2012), but there seems to be a gap between forecasting lightning and administrating public health warnings, and sensitive populations are not always effectively alerted when thunderstorms are expected. This paper's objective is to describe the first thunderstorm asthma event in Israel, which occurred during an unusually strong convective storm on 25 October 2015. We present the meteorological and electrical circumstances leading to a notable increase in ER presentations of patients with respiratory problems immediately after the passage of the storm.

\section{Data sources}

We used data from various sources for studying possible correlations between meteorological conditions, lightning occurrence, aerosol concentrations, pollen counts and respiratory illnesses for central Israel. a. Lightning data was obtained from the Israeli Lightning Detection Network (ILDN) operated by the Israeli Electrical Corporation (IEC). The system and its capabilities are described by Shalev et al. (2011).

b. Meteorological data (temperature, humidity, wind and pressure) were obtained from the Israeli Meteorological Service (IMS) for selected stations throughout the country.

c. For aerosol data, we used the $\mathrm{PM}_{2.5}$ and $\mathrm{PM}_{10}$ data collected routinely by the Ministry of Environmental Protection in Israel, which operates a national network of $>40$ stations. These stations report particle concentrations at $5 \mathrm{~min}$ intervals. That system also records ground-level ozone data.

d. Regarding pollen data, the daily average pollen and spore concentrations (number per $\mathrm{m}^{3}$ ) were obtained from the Ted Arison Laboratory for Monitoring Airborne Allergens at Tel Aviv University. The species are listed in Appendix A.

e. Hospital presentation records for patients with respiratory symptoms of specific ICD (International Classification of Diseases) codes at the Emergency Room (ER) were collected from three Israeli hospitals for a specific list of allergy-related illnesses. Approval of the internal Helsinki committee in each hospital was obtained. The long-term averages were obtained from hospital records to establish the baseline.

\section{Meteorological conditions}

The synoptic condition leading to the unusual event described here are summarized by Razy et al. (2018) and will be briefly described below. During 24 October 2015 the eastern Mediterranean was dominated by a Red Sea Trough (RST; Ben-Ami et al., 2015), a low-pressure region extending from the south along the Red Sea northward to the eastern Mediterranean. This system transported tropical air toward Egypt, Jordan, Israel, Lebanon and Cyprus in the lower levels $(850 \mathrm{hPa})$. At the upper levels $(500 \mathrm{hPa})$, a pronounced trough was situated with the axis slanted between Crete and Cyprus. This trough had two effects: one was a transport of tropical air by the south-southwesterly winds aloft and second was upward motion at the middle levels, induced by positive vorticity advection ahead of this trough. Prior to the beginning of the storm, a cold front was noted west of the Israeli coast. At the same time a mesoscale cyclone was formed over the Sinai Peninsula and the southeastern Mediterranean, organizing the flow that advected moist air from the sea. During the morning hours of 25 October, the cyclone, together with the cold front, moved inland. Around 09:00 LT this multicellular cold front crossed central Israel, accompanied by extremely developed thunderclouds, with tops reaching $17 \mathrm{~km}$ 


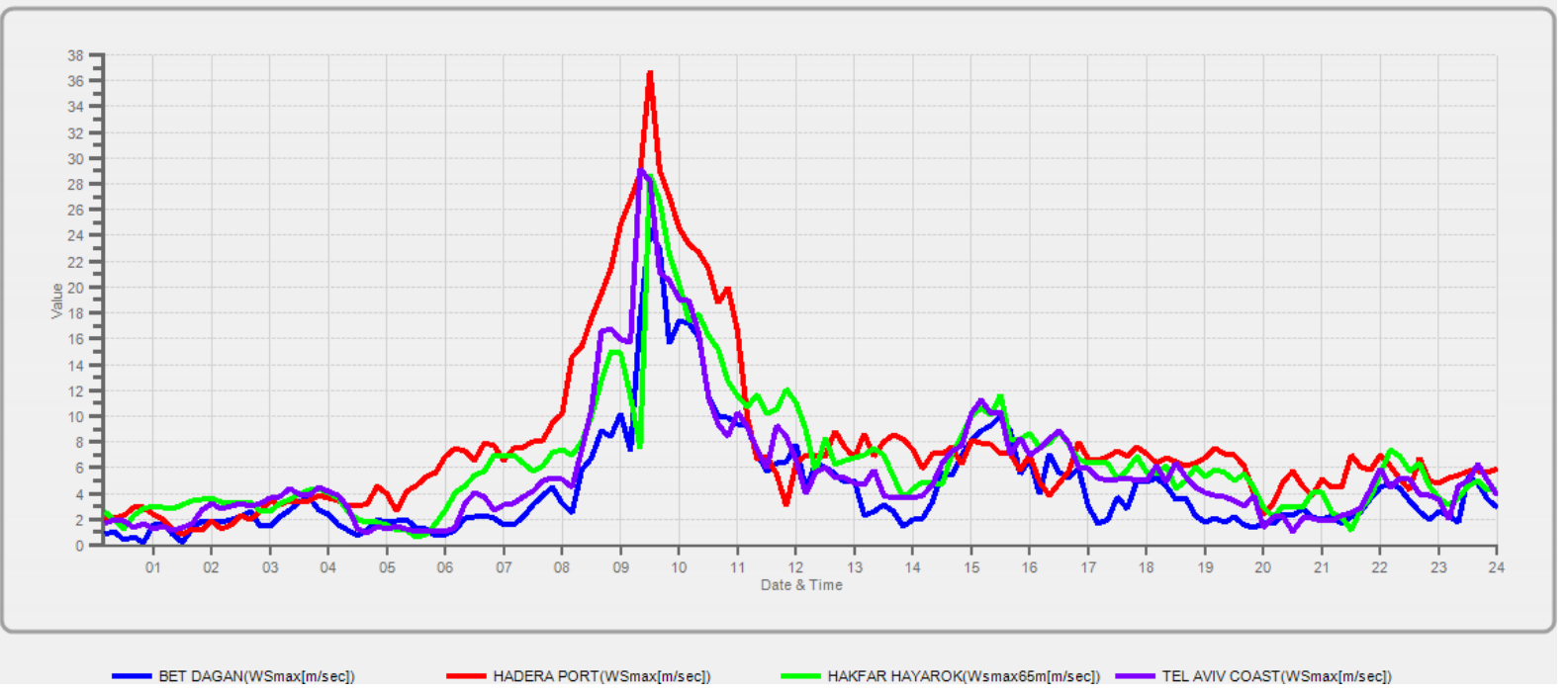

Figure 2. Wind speed at four different stations along Israel. Bet Dagan (in blue) is located $12 \mathrm{~km}$ southeast of Tel Aviv. The port of Hadera (red) is located on the coastline, $45 \mathrm{~km}$ north of Tel Aviv. Hakfar Hayarok (green) is $5 \mathrm{~km}$ northeast of Tel Aviv, and Tel Aviv coast (purple) is located on the Mediterranean coastline. All stations recorded an abrupt and short-lived increase in wind speed around 10:00 LT, indicating the passage of the gust front. Data courtesy of the IMS.

height. The highly populated area of central Israel, extending from the coastal region inland, was subjected to torrential rains for $1-2 \mathrm{~h}$ and large hailstorm with hail of over $5 \mathrm{~cm}$ diameter. Rain-gauge data obtained from the IMS show that in several places in central Israel the $10 \mathrm{~min}$ rain rate exceeded $100 \mathrm{~mm} \mathrm{~h}^{-1}$ with a total of $>50 \mathrm{~mm}$ in the entire event (constituting $\sim 10 \%$ of the annual average). The intensity of the storm can be attributed, at least partly, to the tropical nature of the warm air transported from south by the Red Sea Trough (RST), ahead of the storm. The multicellular system subsided upon reaching the Jordan rift in eastern Israel. The entire event caused one fatality, extensive flooding in several Israeli cities and agricultural damage. It also impacted the national electrical grid with power outages lasting up to 3 days in central Israel. This was the most powerful thunderstorm ever observed in Israel since the ILDN became operational in 1997.

a. Wind - based on the IMS data, the storm was typified by destructive southwesterly winds that exceeded $25 \mathrm{~m} \mathrm{~s}^{-1}$, with gusts of $>36 \mathrm{~m} \mathrm{~s}^{-1}$, which can be attributed to the downbursts from the active cells. Figure 2 presents wind speeds measured at several locations. The distance from the Tel Aviv coast (purple line) to the port of Hadera (red line) is approximately $40 \mathrm{~km}$, indicating a very wide gust front that swept across central Israel together with the movement of the active cells. The sustained high winds lasted for more than $2 \mathrm{~h}$, and caused a significant increase in amounts of airborne particulate matter (see below). b. Electrical activity - more than 17000 cloud-to-ground (CG) lightning strikes were registered by the ILDN during this event, exceeding the annual total amount of lightning strikes for the entire country (Fig. 3b). As Fig. 4 shows, at the peak of the event the average CG flash rates between 09:00 and 09:30LT were greater than 450 strikes per minute. One should consider that this is only the CG flash rate as the ILDN does not record intracloud flashes (IC). If we accept the ratio of IC / CG $\sim 2$ reported by Yair et al. (1998), then the total flash rate would be more than 1000 flashes per minute, exceeding the maximum global record of flash rates found at the Argentina-Paraguay border (Zipser et al., 2006).

\section{Particle concentrations}

The results from the Israeli Ministry for Environmental Protection's air-quality monitoring network show a remarkable increase in the concentrations of $\mathrm{PM}_{2.5}$ particles, up to 10fold the normal values (Fig. 5). This is due to the very strong winds ahead of the cells, which picked up considerable amounts of dust, pollen and other types of aerosols from the surface.

The daily pollen amounts for October 2015 (Fig. 6) exhibit two significant peaks, which are related to severe weather events. It should be noted that before the onset of the storm on 25 October, there were already greater than usual amounts of pollen and spores in the air (up to a factor of 3). This sup- 
(a)

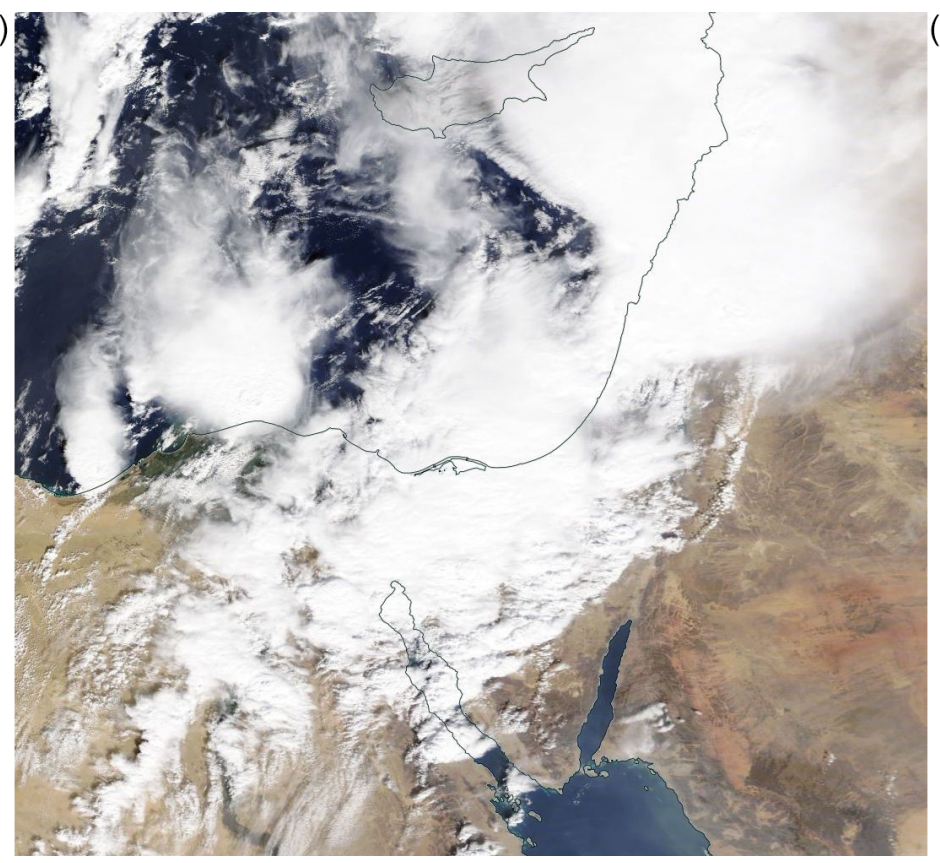

(b)

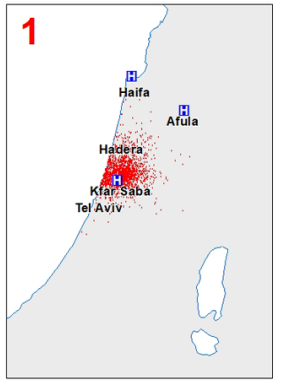

Time frame 09:00-09:30

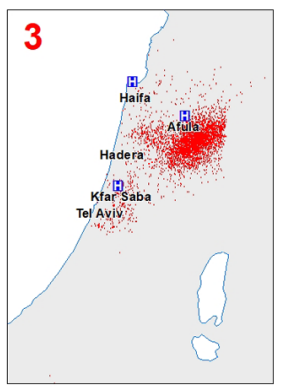

Time frame 10:00-10:30 Time frame 10:30-11:00

Time frame 09:30-10:00
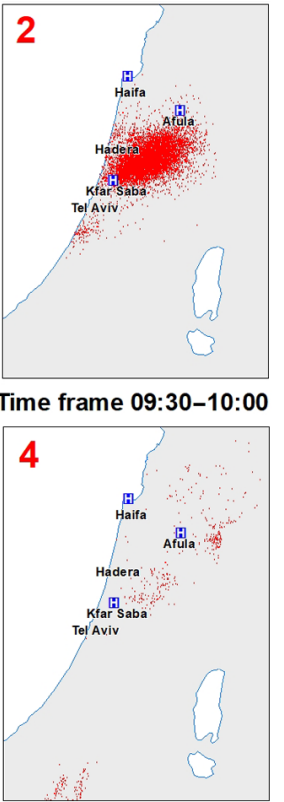

Figure 3. (a) Visible MODIS satellite image at 12:00 UT when the cold front and thunderstorms had moved into Israel. (b) Lightning strikes detected on 25 October 2015 by the ILDN (Israel Lightning Detection Network) operated by the IEC. Each point is a ground strike. The panels show cumulative values at $30 \mathrm{~min}$ intervals, local time and the location of the three hospitals involved in the research.

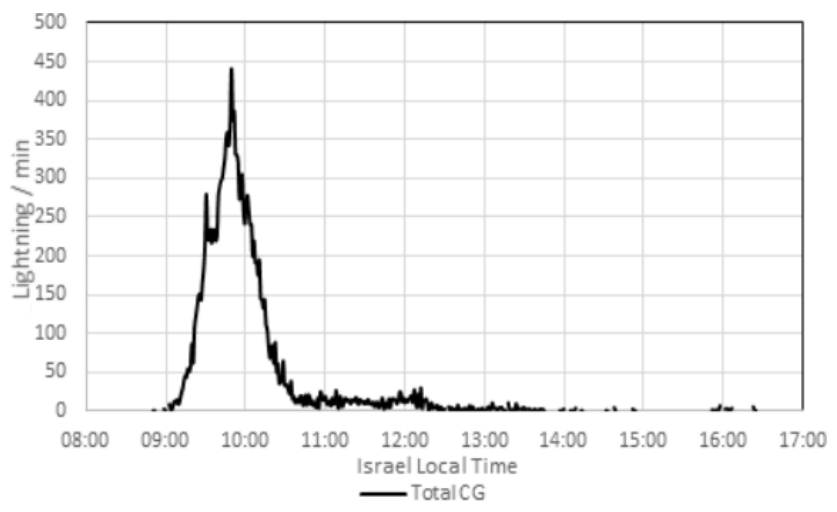

\section{Hospital ER presentations}

The hospital presentation records of patients with respiratory problems were obtained from three Israeli hospitals. The Meir Medical Center is located in the city of Kfar Saba (population 110000$), 15 \mathrm{~km}$ northeast of Tel Aviv in the central coastal plain. The Ha'Emek Medical Center is located in the city of Afula (population 43000 ), a regional urban center located in an agricultural and rural part of northern Israel, close to Mt. Tabor. The Rambam Medical Center is located in Israel's largest port city of Haifa (population 280000 ) and is the largest of the three. Figure 7 shows the records of a full week with numbers of patients, starting 3 days before the event. The ER presentation records show that the numbers of presentations of patients on 25 October increased compared with the numbers of the days before the storm. Although in absolute numbers the numbers may seem low, the values admitted on the day of the thunderstorm represent a clear deviation from monthly average for October. At the Meir (located just below the ground track of the storm cells) and Rambam (located west of the ground track) hospitals there was a clear increase in the number of ER presentations which could be related to the passage of the gust front in the surrounding areas and the ensuing increase in particle concentrations. Based on records of arrival times at the ER, we noted that within several hours after the thunderstorm there was a noticeable increase in the number of patients with respiratory problems of a specific nature (a list of diagnoses only related to asthma and allergic respiratory diseases), in line with the pattern re- 

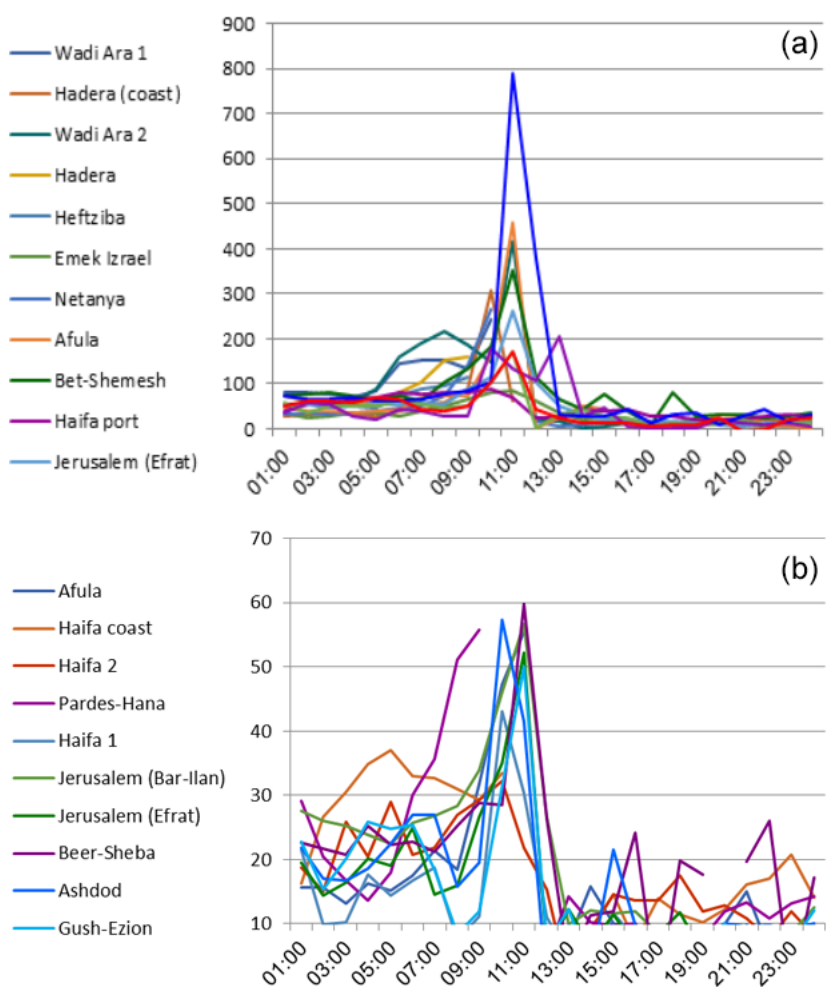

Figure 5. (a) Mass concentration of $\mathrm{PM}_{10}$ aerosols for several stations in central Israel, 25 October 2015. Data are given in $\mu \mathrm{g} \mathrm{m}^{-3}$. Note the peak around 11:00LT, coinciding with the passage of the gust front. The sharp, strong peak was measured at the Rambam Medical Center in Haifa. (b) The same as in (a), for $\mathrm{PM}_{2.5}$ aerosol concentrations.

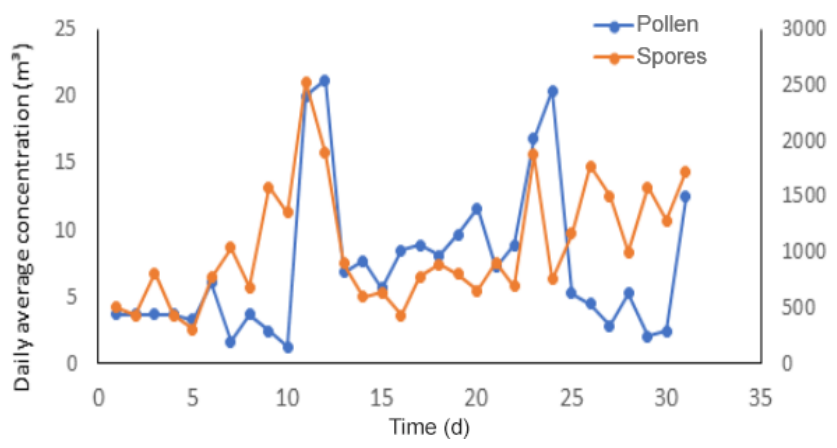

Figure 6. Daily average concentrations of pollen and spore numbers for October 2015, based on data collected at Tel Aviv University's monitoring station in the botanical gardens on campus (data courtesy of Amram Eshel, the Laboratory for Pollen Monitoring, Tel Aviv University).

ported by Newson et al. (1997) and Thien et al. (2018). At the Ha'Emek medical center in Afula there was a small decrease and the numbers were almost the same as the day before. In all three hospitals, this increase in patient presentation to the ER with respiratory problems persisted for $24 \mathrm{~h}$ and a clear decline was noticed in the following day, likely related

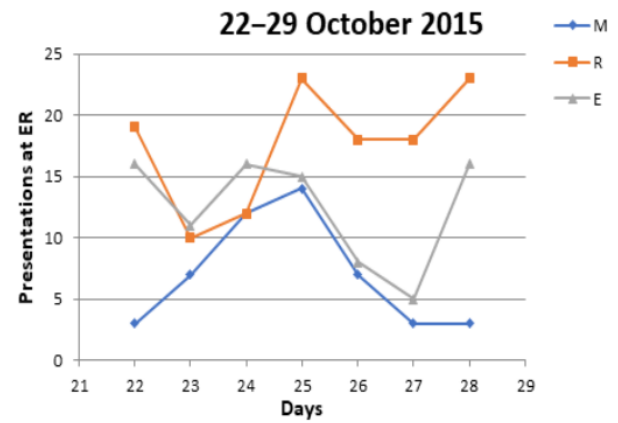

Figure 7. Emergency room presentations at three Israeli hospitals in the 3 days preceding and following the 25 October 2015 supercell event: Meir Medical Center (blue), Rambam Medical Center (orange) and Ha'Emek Medical Center (grey).

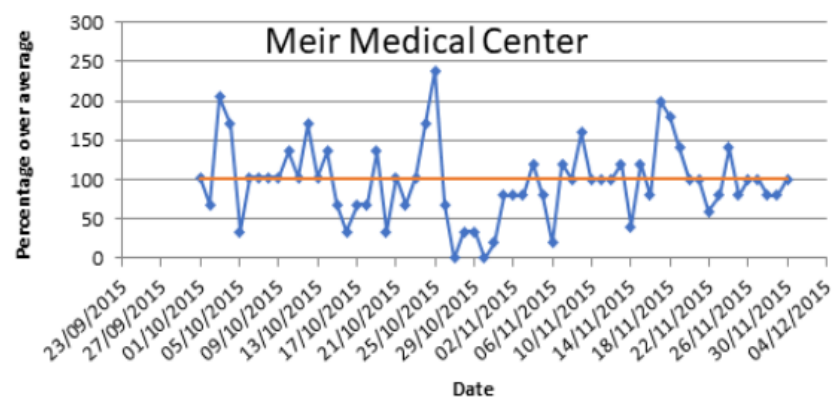

Figure 8. Two months of ER presentations of patients with respiratory problems at the Meir Medical Center in Kfar Saba, central Israel (for the period 1 October to 30 November 2015). The 25 October record shows a $250 \%$ increase in a single day.

to a wash-out effect by precipitation that followed the passage of the active cells. This decline was more pronounced at the Meir and Ha'Emek hospitals which experienced heavy rains during the storm, lasting for $48 \mathrm{~h}$. At the Rambam Medical Center in Haifa the numbers of ER presentations with respiratory problems rose again to high values, likely due to the ambient values of air pollution related to aerosols in the Bay of Haifa, a well-known source of industrial emissions (Saaroni et al., 2018).

\section{Discussion}

In most reported cases of thunderstorm asthma in Europe, Canada, USA and Australia, the initiating agents were spring or summer convective storms, and their occurrence coincided with the flowering season of many plant species whose pollen is known to be highly allergenic. In Israel, thunderstorms and lightning occurs mainly during winter months (DecemberJanuary-February) and are associated with the passage of Cyprus Lows or the RST (Ziv et al., 2008; Shalev et al., 2011; Yair et al., 2014; Ben-Ami et al., 2015). During these months there is little flowering and pollen concentrations are low (Keinan, 1992). However, some of the most severe con- 
vective events in Israel occur during fall and spring months, when the RST pressure system transports mid-level moisture into the eastern Mediterranean and the atmosphere is unstable, enabling deep convection and intense lightning activity. These events occur mostly in October-November and March-May, and coincide with flowering of various allergenbearing plant species, for example Ambrosia spp. (Waisel et al., 1997, 2008; Appendix A), and so have the potential to instigate thunderstorm-associated asthma epidemics.

The 25 October 2015 supercell event was by far one of the strongest thunderstorm episodes ever recorded in Israel (Razy et al., 2018). The unique synoptic circumstances of this event coincided with massive flowering of Ambrosia spp. already shown to be highly allergenic and widespread in central Israel (Yair et al., 2017, 2019). Previous studies suggested that the mechanism by which thunderstorm dynamics recycle ambient aerosols is very effective in releasing allergens from pollen particles that may otherwise not reach and affect sensitive populations (Taylor and Jonsson, 2004; D'Amato et al., 2015). The strong electric fields that existed during the thunderstorm, manifested by the high flash rate, as well as the high humidity and presence of rain, likely aided in rupturing the pollen membranes and enriching the air with respirable allergens that accompanied other aerosol particles already present in the environment. The track of the storm passed directly above a densely populated, mostly urban part of Israel, where the ambient concentrations of pollution particles were already high. Additionally, as the spore counts indicate (Fig. 6), the background levels of fungal spores, which may play an important role in triggering allergenic asthma (Packe and Ayers, 1986; Dales et al., 2003), were high the day before the storm. Thus, it was the convergence of several factors on the particular day that initiated the observed increase in ER respiratory presentations. Admittedly, the public health data presented in this study are limited, but follow-up research being presently conducted will help us to understand the characteristics of admitted patients (as performed by Thien et al., 2018).
What can be done to protect sensitive populations against thunderstorm asthma, especially in light of the emerging trends of thunderstorm frequency (Romps et al., 2014; Brooks, 2013; Diffenbaugh et al., 2013; Trapp et al., 2017; Yair et al., 2019), the extended period of plant flowering (Ziska et al., 2011) and the increase in allergen content in pollen (Singer et al., 2005) in a warmer climate? A thorough review published by the World Allergy Organization (D'Amato et al., 2015) surveyed the expected changes in the occurrence of thunderstorm asthma and concluded that people with hypersensitivity to pollen should be advised to stay indoors when there are clear indications that thunderstorm activity is expected. Silver et al. (2018) examined the seasonality and predictability of asthma-related presentations at Melbourne hospitals using a time series ecological approach. They suggest that the observed spring peak in asthma patient numbers may be related to thunderstorm asthma as they are associated with rainfall, high humidity and enhanced grass pollen levels, but the rarity of such events undermines predictive capabilities. Indeed, early warning capabilities for lightning are becoming operational in some countries. For example, the LPI calculated from the microphysical fields of numerical models such as the WRF is being used for mediumrange weather forecast models (Lynn and Yair, 2010; Lynn et al., 2012), and pollen forecast models are also used to predict the onset and spread of pollen concentrations (Sofiev et al., 2013; Zhang et al., 2014). However, there seems to be a gap between a combined forecasting procedure of pollen and lightning and administering public health warnings, and thus sensitive populations may not be effectively alerted. We therefore suggest to include proper public health alerts when there is a clear indication of the coincidence of thunderstorms and the plant flowering season in specific regions where allergenic species are found.

Data availability. Public health records from the hospitals that participated in this research are restricted and cannot be accessed publicly but may be requested from the corresponding author. Meteorological information and aerosol data are publicly available at the Israeli Meteorological Data Repository at https://ims.data.gov.il/ (last access: November 2019). The IEC lightning data are commercial and property of the company and can be shared upon request. Pollen data from Amram Eshel's observations are hosted in Tel-Aviv University servers and can be made available upon request (not openly accessible). 


\section{Appendix A}

Table A1. Table showing flowering months for various allergenic plants in Israel (based on Keinan, 1992). Yellow marks little flowering, dark brown marks massive flowering.

\begin{tabular}{|c|c|c|c|c|c|c|c|c|c|c|c|c|}
\hline & 1 & 2 & 3 & 4 & 5 & 6 & 7 & 8 & 9 & 10 & 11 & 12 \\
\hline Cynodon dactylon & & & & & & & & & & & & \\
\hline Hyparrhenia hirta & & & & & & & & & & & & \\
\hline $\begin{array}{l}\text { Pennisetum } \\
\text { clandestinum }\end{array}$ & & & & & & & & & & & & \\
\hline $\begin{array}{l}\text { Stenotaphrum } \\
\text { secundatum }\end{array}$ & & & & & & & & & & & & \\
\hline Paspalum vaginatum & & & & & & & & & & & & \\
\hline Zoisia sp. & & & & & & & & & & & & \\
\hline Sorghum halepense & & & & & & & & & & & & \\
\hline Chloris gayana & & & & & & & & & & & & \\
\hline Poa sp. & & & & & & & & & & & & \\
\hline Hordeum $\mathrm{sp}$. & & & & & & & & & & & & \\
\hline Lolium sp. & & & & & & & & & & & & \\
\hline Bromus sp. & & & & & & & & & & & & \\
\hline Dactylis glomerata & & & & & & & & & & & & \\
\hline Avena sp. & & & & & & & & & & & & \\
\hline Parietaria sp. & & & & & & & & & & & & \\
\hline Ricinus communis & & & & & & & & & & & & \\
\hline Chenopodium sp. & & & & & & & & & & & & \\
\hline Urtica $\mathrm{sp}$. & & & & & & & & & & & & \\
\hline Mercurialis annua & & & & & & & & & & & & \\
\hline Plantago sp. & & & & & & & & & & & & \\
\hline Amaranthus sp. & & & & & & & & & & & & \\
\hline Inula viscosa & & & & & & & & & & & & \\
\hline Ambrosia sp. & & & & & & & & & & & & \\
\hline Xanthium sp. & & & & & & & & & & & & \\
\hline Salsola kali & & & & & & & & & & & & \\
\hline Atriplex halimus & & & & & & & & & & & & \\
\hline Artemisia monosperma & & & & & & & & & & & & \\
\hline Artemisia herba alba & & & & & & & & & & & & \\
\hline Eucalyptus sp. & & & & & & & & & & & & \\
\hline Thuja sp. & & & & & & & & & & & & \\
\hline Cupressaceae & & & & & & & & & & & & \\
\hline Phoenix dactylifera & & & & & & & & & & & & \\
\hline Quercus ithaburensis & & & & & & & & & & & & \\
\hline Quercus calliprinos & & & & & & & & & & & & \\
\hline Pistacia lentiscus & & & & & & & & & & & & \\
\hline Pistacia palaestina & & & & & & & & & & & & \\
\hline Olea europaea & & & & & & & & & & & & \\
\hline Acacia sp. & & & & & & & & & & & & \\
\hline Carya illinoinensis & & & & & & & & & & & & \\
\hline Ailanthus glandulosa & & & & & & & & & & & & \\
\hline Ceratonia siliqua & & & & & & & & & & & & \\
\hline Schinus sp. & & & & & & & & & & & & \\
\hline Casuarina sp. & & & & & & & & & & & & \\
\hline
\end{tabular}


Author contributions. YoY and YiY initiated and led this research. YoY performed the analysis of lightning and aerosol time series and wrote the paper. YiY analyzed pollen data and hospital admission records and produced maps and graphs. BR helped with ambrosia pollen analysis and data. RCC, YR, ES and MR helped in analyzing emergency room admission records and contributed equally to this work.

Competing interests. The authors declare that they have no conflict of interest.

Acknowledgements. This research is supported by the Israeli Science Foundation and the National Chinese Science Foundation grant no. 2460/17. Pollen data courtesy of Amram Eshel, Tel Aviv University. Lightning data obtained from the Israeli Electrical Corporation (IEC). We wish to thank Nurit Keinan for her kind help with Appendix A. Thanks are due to Mordechai Yaffe for his help with lightning maps.

Financial support. This research has been supported by the Israel Science Foundation (grant no. 2460/17).

Review statement. This paper was edited by Maria-Carmen Llasat and reviewed by two anonymous referees.

\section{References}

Andrew, E., Nehme, Z., Bernard, S., Abramson, M. J., Newbigin, E., Piper, B., Dunlop, J., Holman, P., and Smith, K.: Stormy weather: a retrospective analysis of demand for emergency medical services during epidemic thunderstorm asthma, Brit. Med. J., 359, j5636, https://doi.org/10.1136/bmj.j5636, 2017.

Beggs, P. J.: Allergen aerosol from pollen-nucleated precipitation: A novel thunderstorm asthma trigger, Atmos. Environ., 152, 455-457, 2017.

Bellomo, R., Gigliotti, P., Treloar, A., Holmes, P., Suphioglu, C., Singh, M. B., and Knox, R. B.: Two consecutive thunderstorm associated epidemics of asthma in the city of Melbourne, Med. J. Aust., 156, 834-837, 1992.

Ben-Ami, Y., Altaratz, O., Yair, Y., and Koren, I.: Lightning characteristics in Eastern Mediterranean thunderstorms during different synoptic systems, Nat. Hazards Earth Syst. Sci., 15, 2449-2459, https://doi.org/10.5194/nhess-15-2449-2015, 2015.

Brooks, H. E.: Severe thunderstorms and climate change, Atmos. Res., 123, 129-138, 2013.

Campbell-Hewson, G., Cope, A., Egleston, C. V., Sherriff, H. M., Robsinson, S. M., and Allitt, U.: Epidemic of asthma possibly associated with electrical storms, Brit. Med. J., 309, 1086-1087, 1994.

Cooper, M. A. and Holle, R. L.: How to make baseline studies of lightning deaths and damages, in: Reducing Lightning Injuries Worldwide, Springer Natural Hazards, Springer, Switzerland, 150-163, https://doi.org/10.1007/978-3-319-77563-0_15, 2019.
Dabrera, G., Murray, V., Emberlin, J., Ayres, J. G., Collier, C., Clewlow, Y., and Sachon, P.: Thunderstorm asthma: an overview of the evidence base and implications for public health advice, QJM: Int. J. Med., 106, 207-217, 2012.

Dales, R. E., Cakmak, S., Judek, S., Dann, T., Coates, F., Brook, J., and Burnett, R.: The role of fungal spores in thunderstorm asthma, Chest, 123, 745-750, https://doi.org/10.1378/chest.123.3.745, 2003.

Dales, R. E., Cakmak, S., Judek, S., et al.: The role of fungal spores in thunderstorm asthma, Chest, 123, 745-750, 2013.

D'Amato, G., Holgate, S. T., Pawankar, R., et al.: Meteorological conditions, climate change, new emerging factors and asthma and related allergic disorders. A statement of the World Allergy Organization, World Allergy Organiz. J., 8, 25-52, https://doi.org/10.1186/s40413-015-0073-0, 2015.

D’Amato, G, Vitale, C., D’Amato, M., Cecchi, L., Liccardi, C., Molino, A., Vatrella, A., Sanduzzi, A., Maesano, C., and AnnesiMaesano, I.: Thunderstorm-related asthma: what happens and why, Clin. Exp. Allergy, 46, 390-396, 2016.

D’Amato, G., Annesi Maesano, I., Molino, A., Vitale, C., and D'Amato, M.: Thunderstorm-related asthma attacks, J. Allergy Clin. Immunol., 139, 1786-1787, 2017.

Diffenbaugh, N. S., Scherer, M., and Trapp, R. J.: Robust increases in severe thunderstorm environments in response to greenhouse forcing, P. Natl. Acad. Sci. USA, 101, 16361-16366, https://doi.org/10.1073/pnas.1307758110, 2013.

Girgis, S. T., Marks, G. B., Downs, S. H., Kolbe, A., Car, G. N., and Paton, R.: Thunderstorm associated asthma in an inland town in south-eastern Australia. Who is at risk?, Eur. Respir. J., 16, 3-8, 2000.

Gleason, J. A., Bielroy, L., and Fagliano, J. A.: Associations between ozone, $\mathrm{PM}_{2.5}$ and four pollen types on emergency department pediatric asthma events during the warm season in New Jersey: A case-cross over study, Environ. Res., 132, 421-429, 2014.

Harun, N.-S., Lachapelle, P., and Douglass, J.: Thunderstormtriggered asthma: what we know so far, J. Asth. Aller., 12, 101108, https://doi.org/10.2147/JAA.S175155, 2019.

Keinan, N.: Comparison of pollen allergenicity of closely related plant populations and species, $\mathrm{PhD}$ dissertation, Tel-Aviv University, Tel-Aviv, 115 pp., 1992.

Knox, R. B.: Grass pollen, thunderstorms and asthma, Clin. Exper. Aller., 23, 354-359, https://doi.org/10.1111/j.13652222.1993.tb00339.x, 1993.

Krausmann, E., Renni, E., and Campedel, M.: Industrial accidents triggered by earthquakes, floods and lightning: lessons learned from a database analysis, Nat. Hazards, 59, 285-300, https://doi.org/10.1007/s11069-011-9754-3, 2011.

Lynn, B. and Yair, Y.: Prediction of lightning flash density with the WRF model, Adv. Geosci., 23, 11-16, https://doi.org/10.5194/adgeo-23-11-2010, 2010.

Lynn, B., Yair, Y., Price, C., Kelman, G., and Clark, A. J.: Predicting Cloud-to-Ground and Intracloud Lightning in Weather Forecast Models, Weather Forecast., 27, 1470-1488, https://doi.org/10.1175/WAF-D-11-00144.1, 2012.

Marks, G. B., Colquhoun, J. R., Girgis, S. T., Koski, M. H., Treloar, A. B., Hansen, P., Downs, S. H., and Car, N. G.: Thunderstorm outflows preceding epidemics of asthma during spring and summer, Thorax, 56, 468-471, 2001. 
Miguel, A. G., Taylor, P. E., House, J., Glovsky, E. M., and Flagan, R. C.: Meteorological influences on respirable fragment release from Chinese Elm pollen, Aerosol Sci. Tech., 40, 690-696, https://doi.org/10.1080/02786820600798869, 2006.

Molfino, N. A., Wright, S. C., Katz, I., Tarlo, S., Silverman, F., McClean, P. A., Slutsky, A. S., Zamel, N., Szalai, J. P., and Raizenne, M.: Effect of low concentrations of ozone on inhaled allergen responses in asthmatic subjects, Lancet, 338, 199-203, 1991.

Nasser, S. M. and Pulimood, T. B.: Allergens and thunderstorm asthma, Curr. Allergy Asthma Rep., 9, 384-390, https://doi.org/10.1007/s11882-009-0056-8, 2009.

Newson, R., Strachan, D. P., Archibald, E., Emberlin, J., Hardaker, P., and Collier, C.: Effect of thunderstorms and airborne grass pollen on the incidence of acute asthma in England, 1990-1994, Thorax, 52, 680-685, 1997.

Packe, G. E. and Ayres, J.: Asthma outbreak during a thunderstorm, Lancet, 326, 199-204, 1985.

Packe, G. E. and Ayres, J.: Aeroallergen skin sensitivity in patients with severe asthma during a thunderstorm, Lancet, 327, 851-852, 1986.

Petrucci, O., Aceto, L., Bianchi, C., Bigot, V., Brázdil, R., Pereira, S., Kahraman, A., Kılıç, Ö., Kotroni, V., Llasat, M. C., Llasat-Botija, M., Papagiannaki, K., Pasqua, A. A., Řehoř, J., Rossello Geli, J., Salvati, P., Vinet, F., and Zêzere, J. L.: Flood Fatalities in Europe, 1980-2018: Variability, Features, and Lessons to Learn, Water, 11, 1682, https://doi.org/10.3390/w11081682, 2019.

Razy, A., Vadislavsky, E., Baharad, A., Halfon, N., Carmona, I., Levi, Y., and Savir, A.: The October 2015 supercell storm in Israel, Eur. Forecast., 23, 43-47, 2018.

Romps, D. M., Seeley, J. T., Vollaro, D., and Molinari, J.: Projected increase in lightning strikes in the United States due to global warming, Science, 346, 851-854, 2014.

Rossi, O. V. J., Kinnula, V. L., Tienari, J., and Huhti, E.: Association of severe asthma attacks with weather, pollen, and air pollutants, Thorax, 48, 244-248, 1993.

Saaroni, H., Levi, E., and Ziv, B.: Particulate matter in the summer season and its relation to synoptic conditions and regional climatic stress - the case of Haifa, Israel, Water Air Soil Poll., 229, 313-331, https://doi.org/10.1007/s11270-018-3943-6, 2018.

Shalev, S., Saaroni, H., Izsak, T., Yair, Y., and Ziv, B.: The spatiotemporal distribution of lightning over Israel and the neighboring area and its relation to regional synoptic systems, Nat. Hazards Earth Syst. Sci., 11, 2125-2135, https://doi.org/10.5194/nhess-11-2125-2011, 2011.

Silver, J. D., Sutherland, M. F., Johnston, F. H., Lampugnani, E. R., McCarthy, M. A., Jacobs, S. J., Pezza, A. B., and Newbigin, E. J.: Seasonal asthma in Melbourne, Australia, and some observations on the occurrence of thunderstorm asthma and its predictability, PLoS ONE, 13, e0194929, https://doi.org/10.1371/journal.pone.0194929, 2018.

Singer, B. D., Ziska, L. H., Frenz, D. A., Gebhard, D. E., and Straka, J. G.: Increasing Amb a 1 content in common ragweed (Ambrosia artemisiifolia) pollen as a function of rising atmospheric $\mathrm{CO}_{2}$ concentrations, Funct. Plant Biol., 32, 667-670, 2005.

Sofiev, M., Siljamo, P., Ranta, H., Linkosalo, T., Jaeger, S., Rasmussen, A., Rantio-Lehtimäki, A., Severova, E., and Kukkonen, J.: A numerical model of birch pollen emission and dispersion in the atmosphere. Description of the emission module, Int.
J. Biometeorol., 57, 45-58, https://doi.org/10.1007/s00484-0120532-z, 2013.

Taylor, P. E. and Jonsson, H.: Thunderstorm asthma, Curr. Allergy Asthma Rep., 4, 409-413, https://doi.org/10.1007/s11882-0040092-3, 2004.

Taylor, P. E., Flagan, R. C., Miguel, A. G., Valenta, R., and Glovsky, M. M.: Birch pollen rupture and the release of aerosols of respirable allergens, Clin. Exp. Allergy, 34, 1591-1596, https://doi.org/10.1111/j.1365-2222.2004.02078.x, 2004.

Thien, F., Beggs, P. J., Csutoros, D., Darvall, J., Hew, M., Davies, J. M., and Byrne, T.: The Melbourne epidemic thunderstorm asthma event 2016: an investigation of environmental triggers, effect on health services, and patient risk factors, Lancet Planet. Health, 2, e255-e263, 2018.

Trapp, R. J., Diffenbaugh, N. S., Brooks, H. E., Baldwin, M. E., Robinson, E. D., and Pal, J. S.: Changes in severe thunderstorm environment frequency during the 21 st century caused by anthropogenically enhanced global radiative forcing, P. Natl. Acad. Sci. USA, 50, 19719-19723, https://doi.org/10.1073/pnas.0705494104, 2017.

Vaidyanathan, V., Miguel, A. G., Taylor, P. E., Flagan, R. C., and Glovsky, M. M.: Effects of electric fields on pollen rupture, J. Allergy Clin. Immunol., 117, S157, https://doi.org/10.1016/j.jaci.2005.12.625, 2006.

Venables, K. M., Allitt, U., Collier, C. G., Emberlin, J., Greig, J. B., Hardaker, P. J., Highham, J. H., Laing-Morton, T., Maynard, R. L., Murray, V., Strachan, D. and Tee, R. D.: Thunderstormrelated asthma - The epidemic of 24/25 June 1994, Clin. Exp. Allergy, 27, 725-736, 1997.

Waisel, Y., Ganor, E., Glikman, M., Epstein, V., and Brenner, S.: Seasonal distribution of airborne pollen in the coastal plain of Israel, Aerobiologia, 13, 127-134, 1997.

Waisel, Y., Eshel, A., Keynan, N., and Langgut, D.: Ambrosia: A new impending disaster for the Israeli allergic population, Israel Med. Assoc. J., 10, 856-857, 2008.

Wardman, A. E., Stefani, D., and MacDonald, J. C.: Thunderstorm associated asthma or shortness of breath epidemic: a Canadian case report, Can. Respir. J., 9, 267-270, 2002.

Williams, E. R., Nathou, N., Hicks, E., Pontikis, C., Russell, B., Miller, M., and Bartholmew, M. J.: The electrification of dustlofting gust fronts ('haboobs') in the Sahel, Atmos. Res., 91, 292-298, 2007.

Yair, Y.: Lightning hazards to human societies in a changing climate, Environ. Res. Lett., 13, 123002, https://doi.org/10.1088/1748-9326/aaea86, 2018.

Yair, Y., Levin, Z., and Altaratz, O.: Lightning phenomenology in the Tel-Aviv area from 1989 to 1996, J. Geophys. Res., 103, 9015-9025, 1998.

Yair, Y., Shalev, S., Erlich, Z., Agrachov, A., Katz, E., Saaroni, H., Price, C., and Ziv, B.: Lightning flash multiplicity in eastern Mediterranean winter thunderstorms, Nat. Hazards Earth Syst. Sci., 14, 165-173, https://doi.org/10.5194/nhess-14-1652014, 2014.

Yair, Y., Sibony, M., and Rubin, B.: Four Ambrosia species in Israel: Invasive, naturalized and casual alien plants, Israel J. Plant Sci., 64, 93-98, 2017.

Yair, Y., Sibony, M., Goldberg, A., Confino-Cohen, R., Rubin, B., and Shahar. E.: Ragweed species (Ambrosia spp.) in Is- 
rael: Distribution and allergenicity, Aerobiologia, 35, 85-95, https://doi.org/10.1007/s10453-018-9542-6, 2019.

Zhang, R., Duhl, T., Salam, M. T., House, J. M., Flagan, R. C., Avol, E. L., Gilliland, F. D., Guenther, A., Chung, S. H., Lamb, B. K., and VanReken, T. M.: Development of a regional-scale pollen emission and transport modeling framework for investigating the impact of climate change on allergic airway disease, Biogeosciences, 11, 1461-1478, https://doi.org/10.5194/bg-111461-2014, 2014.

Zipser, E. J., Liu, C., Cecil, D. J., Nesbitt, S. W., and Yorty, D. P.: Where are the most intense thunderstorms on Earth?, B. Am. Meteorol. Soc., 687, 1057-1071, https://doi.org/10.1175/BAMS-878-1057, 2006.
Ziska, L., Knowlton, K., Rogers, C., Dalan, D., Tierney, N., Elder, M. A., Filley, W., Shropshire, J., Ford, L. B., Hedberg, C., Fleetwood, P., Hovanky, K. H., Kavanaugh, T., Fulford, G., Vrtis, R. F., Patz, J. A., Portnoy, J., Coates, F., Bielory, L., and Frenz, D.: Recent warming by latitude associated with increased length of ragweed pollen season in central North America, P. Natl. Acad. Sci. USA, 108, 4248-4251, 2011.

Ziv, B., Saaroni, H., Yair, Y., Ganot, M., Baarad, H., and Isaschari, D.: Atmospheric factors governing winter thunderstorms in the coastal regions of the eastern Mediterranean, Theor. Appl. Climatol., 95, 301-310, https://doi.org/10.1007/s00704-008-00086, 2008. 